DOI: $10.31073 / \mathrm{mivg} 201801-114$

Available (PDF): http://mivg.iwpim.com.ua/index.php/mivg/article/view/114

УДК 631.67:63.001.05;63.001.57

\title{
ВРАХУВАННЯ ЗМІН КЛІМАТУ ТА ІНТЕНСИВНОСТІ ПОСУХ ПРИ ПЛАНУВАННІ ЗРОШЕННЯ В ЗОНІ ПІВДЕННОГО СТЕПУ УКРАЇНИ
}

О.І. Жовтоног ${ }^{1}$, док. с.-г. наук, Л.А. Філіпенко ${ }^{2}$, канд. геогр. наук, Т.Ф. Деменкова ${ }^{3}$, В.В. Поліщук ${ }^{4}$, канд. с.-Г. наук, Я.О. Бутенко

1,2,3,4.5 - Інститут водних проблем і меліорації НААН, Київ, Україна;

e-mail: olgazhovtonog10@gmail.com, filipenkolaris@gmail.com, tdemenkova@ukr.net,

vitaliypolishchuk@ukr.net, iarynabulba@gmail.com

\begin{abstract}
Анотація. Виконано оиінку змін теплового режиму та природної вологозабезпеченості на півдні Украйни, визначено зміну середньодекадної температури повітря, суми опадів та збільиення частоти і інтенсивності посуиливих явищ. На основі аналізу даних наземних спостережень та обробітку даних дистанційного зондування Землі запропоновано методи адаптації режимів зрочення до посуиливих явии.

Ключові слова: зміни клімату, дистанційне зондування Землі, коефіцієнт природного зволоження, посуха, біокліматичний коефіцієнт, водоспоживання
\end{abstract}

\begin{abstract}
Адаптація сільськогосподарського виробництва до змін клімату.

Глобальні зміни клімату та вплив антропогенної діяльності на ці процеси є міжнародною проблемою щодо відпрацювання інтегрованих заходів для адаптації до цих змін як на рівні країн, так і секторів економіки у цих регіонах.
\end{abstract}

Разом із потеплінням, все частіше спостерігаються прояви цілої низки негативних природних явищ, таких як підвищення кількості та інтенсивності посух, чергування посушливих періодів із періодами зі зливовими опадами та повенями та ін. [1]. Нещодавніми прикладами аномальних явищ в Україні було випадіння снігу у квітні, аномальне похолодання у травні 2017 р. та березні 2018 р., а також тривала посуха у більшості регіонів влітку 2017 р. Найбільш потерпає від зростання посух та шкідливої дії води при повенях аграрне виробництво, особливо у зоні Південного Степу.

Дослідженнями [2] доведено наявність в останні десятиріччя стійкої тенденції до збільшення посушливості клімату та зростання максимальних температур влітку, що призвело до збільшення періоду вегетації культур на два тижні. За таких тенденцій значно підвищується роль зрошення, як важливого заходу адаптації агарного виробництва до змін клімату [3]. Державну політику у галузі водного господарства та меліорації земель орієнтовано на залучення інвестицій в модернізацію, реконструкцію, розвиток зрошувальних систем та забезпечення сталого використання зрошення в першу чергу у Південному регіоні країни [4]. Вирішення проблеми відновлення та модернізації зрошувальних систем вимагає перегляду існуючих нормативів водопотреби у зрошенні. Для використання цих норм при плануванні відновлення, модернізації зрошувальних систем та їх експлуатації важливо враховувати не тільки сучасні зміни клімату, але й імовірні сценарії впливу цього процесу на майбутнє. Одним 3 таких сценаріїв $\epsilon$ припущення продовження існуючої тенденції збільшення посушливості клімату на півдні України [2].

Для запобігання негативних наслідків збільшення посушливості клімату та прояву посух необхідна адаптація зрошуваного землеробства як до глобальних змін клімату, так i до варіації екстремальних погодних явищ. Однією з важливих заходів такої адаптації $€$ впровадження сучасних методів планування водокористування і режимів зрошення 3 урахуванням біологічних особливостей сільськогосподарських культур, властивостей грунтів, технологій зрошення, економічних, екологічних показників, соціальних умов сільської місцевості. Приватні інвестори вже починають вкладати власні кошти у реконструкцію та відновлення внутрішньогосподарських зрошувальних систем та насосних станцій, що забезпечить необхідну водоподачу для поливу сільськогосподарських культур у пікові періоди водопотреби у зрошенні. Все більше аграрних підприємств також вдаються до використання сучасних засобів наземного та космічного агромоніторингу і застосування 
інформаційних систем для удосконалення управління технологіями зрошуваного землеробства. У період 2012-2017 років у господарствах Херсонської області на площах до 10000 га впроваджувалась інформаційна система оперативного планування зрошення «ГІС Полив» [5], виконувалась оцінка стану посівів та якості поливів із використанням космічних знімків $[6,7]$. Поряд із забезпеченням оптимального водного режиму грунту при управлінні зрошенням в умовах посухи важливим $\epsilon$ управління тепловим режимом приземного шару грунту для запобігання негативного впливу високих температур на продукційний процес рослин та процес їх водоспоживання. 3 метою адаптації існуючих методів довгострокового та оперативного планування зрошення до глобальних кліматичних змін та проявів посухи необхідним $\epsilon$ проведення комплексних досліджень кліматичних змін на рівні регіонів та проявів посух протягом вегетації сільськогосподарських культур на рівні окремих господарств, що мають певну спеціалізацію та застосовують інтенсивне зрошення 3 використанням різних технологій.

Мета та методика досліджень. Метою досліджень було визначення напрямків удосконалення методів довгострокового та оперативного планування зрошення на основі вивчення тенденцій загальних змін клімату у регіоні Південного Степу України та особливостей прояву посух при сучасній практиці зрошення дощуванням.

Дослідження проводили паралельно на двох рівнях. На регіональному рівні на прикладі даних багаторічних спостережень (1992-2017 рр.) на метеостанції Херсон у Херсонській області вивчалась динаміка температури повітря та випадіння опадів, а також зміни умов природного зволоження у зоні Південного Степу за даними 15 метеостанцій.

На локальному рівні окремих господарств Херсонської області (Державне підприємство «Дослідне господарство «Асканійське» Асканійської державної сільськогосподарської дослідної станції Інституту зрошуваного землеробства Національної академії аграрних наук України» і Приватне акціонерне товариство «Фрідом Фарм Інтернешнл») виконували дослідження варіації погодних умов протягом вегетаційних сезонів 2012-2017 років та їх вплив на продуктивність сої при поливі дощуванням. У дослідженнях використовували дані впровадження інформаційної системи оперативного планування зрошення IC «ГIC
Полив» [5] та системи космічного агромоніторингу стану посівів (Fieldlook» [8]. Основна увага приділялася оцінці динаміки метеопоказників, від яких в основному залежить випаровуваність у приземному шарі повітря та сумарне випаровування сільськогосподарських культур, тобто температурі і вологості повітря, швидкості вітру та кількості опадів. Для характеристики теплозабезпеченості міжфазних періодів було розглянуто добову динаміку температури повітря (середньої, максимальної та мінімальної), а також суми активних температур, відносну вологість повітря (\%).

Природну вологозабезпеченість території оцінювали за кількістю опадів, їхнім розподілом протягом вегетації сої за формулою 1:

$$
\mathrm{K}_{3}=\frac{\sum \boldsymbol{P}+\boldsymbol{W}_{n}}{\sum \boldsymbol{E}},
$$

де P i E - середня багаторічна сума опадів і випаровуваності за період вегетації сої; $W_{n}-$ активні вологозапаси метрового шару грунту на початку весни

Протягом років досліджень було вивчено частоту та ступінь прояву посух та суховіїв, їх вплив на продуктивність сої та розвиток біомаси рослин у кожному вегетаційному сезоні. Для оцінки посух використовували такі критерії:

- тривалість бездощового періоду, коли протягом 10 і більше днів не було опадів, або їхня добова кількість не перевищувала 1 мм за добу;

- кількість днів з суховіями, коли спостерігались денні температури повітря вище $30^{\circ} \mathrm{C}$, відносна вологість повітря менше $30 \%$, швидкість вітру більше 5 м/с [9];

- інтенсивність посухи за гідротермічним коефіцієнтом Селянінова (ГТК) [10-12].

$$
\boldsymbol{K}=\frac{P * 10}{\sum t},
$$

де $\mathrm{P}$ - сума опадів в мм за міжфазний період, $\Sigma \mathrm{t}$ - сума температур за даний період.

У локальних умовах двох господарств аналіз прояву посухи виконували за міжфазними періодами: посів - сходи - 3-й лист бутонізація - цвітіння - формування бобів дозрівання, а потім об’єднували їх у три періоди: початковий, критичний та період дозрівання.

Сумарне водоспоживання сої та оцінка приросту іï біомаси здійснювали за результатами обробки даних космічних знімків за допомогою інформаційної системи «Fieldlook», що надавалися один раз на тиждень. При аналізі 
даних космічних знімків величину біомаси пов'язували з величиною транспірації рослин та факторами, що іï̈ обмежували. При наявності хмарності супутникові дані коригували за допомогою наземних спостережень або розрахункових даних IC «ГІС Полив».

Результати досліджень. Врахування змін клімату при визначенні водопотреби у зрошенні сільськогосподарських культур у зоні Південного Степу

На рис. 1 наведено динаміку середньої температури повітря за вегетаційний період 1992-2017 pр., де прослідковується зростання цього показника починаючи 31998 р. порівняно 3 середньобагаторічним значенням, що становить $15,7^{\circ} \mathrm{C}$.

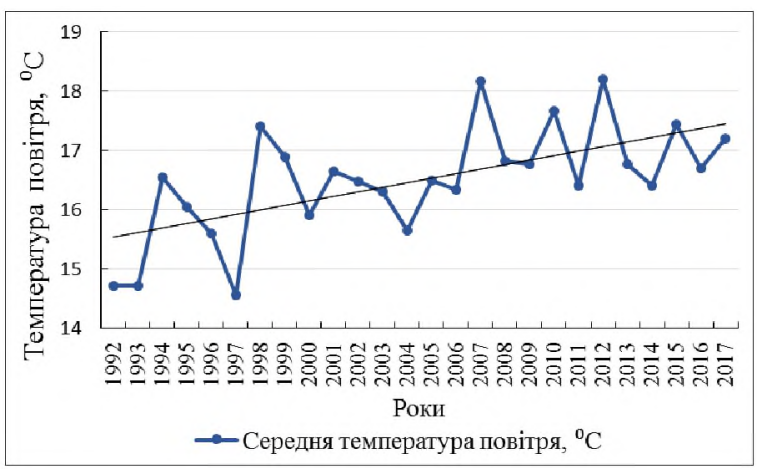

Рис. 1. Динаміка температури повітря

Аналіз багаторічного ряду суми опадів виявив тенденцію до їх зростання протягом всього періоду вегетації, що призвело до пере- вищення кліматичної норми (222 мм) у середньому на 55 мм. Лише у 6-ти випадках сума опадів була меншою за норму, у інші роки їх кількість коливалась у межах 250-400 мм, що складає 113-180\% від норми. Найбільші опади випадали у 1997, 2000 та 2016 роках, коли їх сума за вегетаційний період перевищувала 400 мм, а найпосушливим був 2007 р. 3 відхиленням суми опадів від середньобагаторічної норми на $66 \%$ (рис. 2).

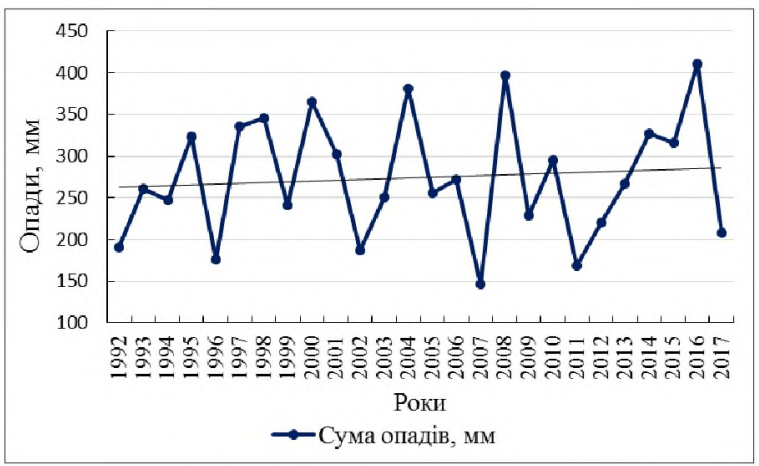

Рис. 2. Динаміка суми опадів

Найбільший приріст опадів спостерігався на початку та у середині вегетаційного періоду (11-18 мм за місяць), фактично не змінилася їхня сума у серпні. На фоні зростання загальної кількості опадів збільшилася частка злив на $15 \%$, що призводило до поверхневого стоку. Також зросла тривалість бездощових періодів, в окремі роки вона досягала декількох декад.

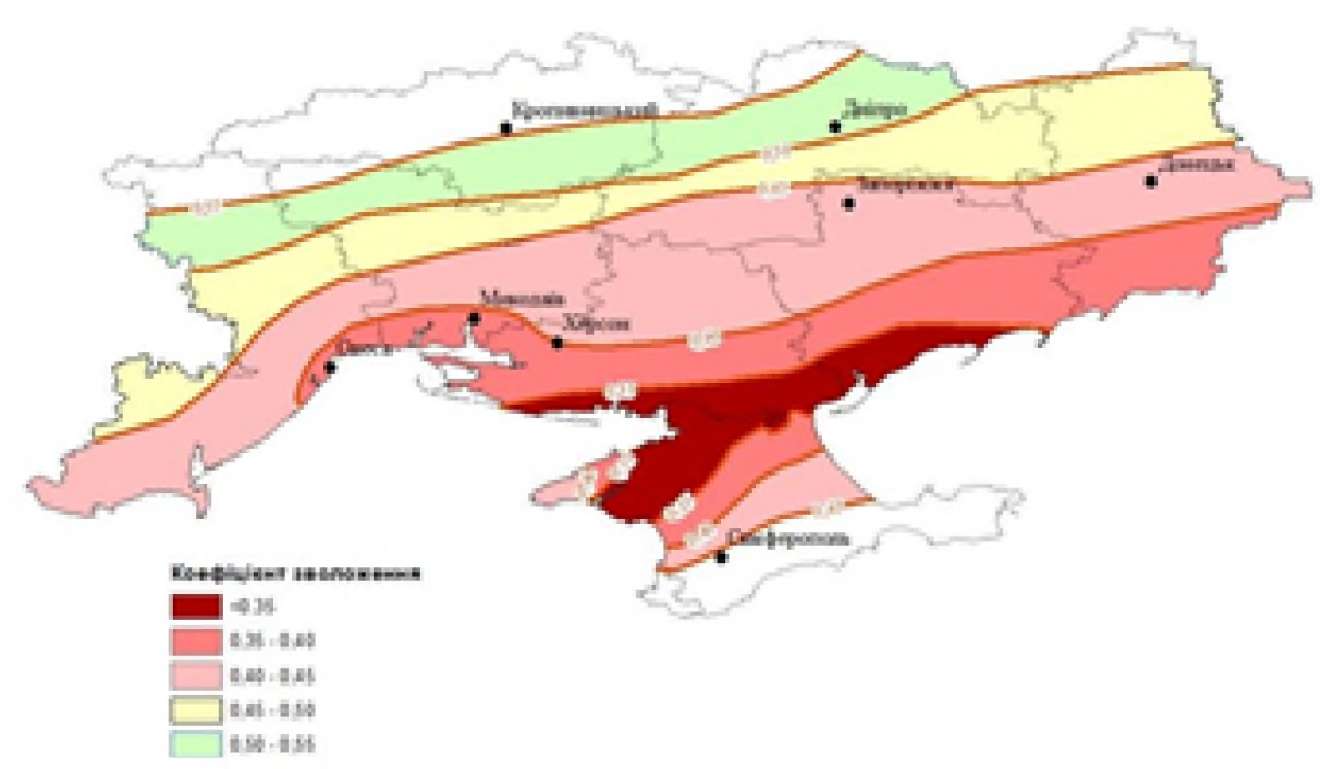

Рис. 3. Карта-схема районування Степу України за коефіцієнтом природного зволоження (Кз) 1991-2016 pp. 
Районування Південного Степу за значеннями коефіцієнта природного зволоження (К3) (рис. 3) показало, що спостерігається поширення території з підвищеною посушливістю, де Кз зменшується на 0,08-0,02, що складає $5-20 \%$ порівняно 3 попереднім районуванням, виконаним наприкінці минулого сторіччя [13]. Значення Кз у прибережній зоні Південного Степу знизилось до 0,35 і нижче, що свідчить про загрозу опустелювання. Додатковим чинником до того ж $є$ знищення лісосмуг, що призводить до посилення вітрової ерозії. У зв'язку з цим було перераховано зрошувальні норми основних сільськогосподарських культур, шо збільшились порівняно 3 попередніми нормативами від 5 до $28 \%$ [14].

Якщо існуюча тенденція зміни клімату збережеться протягом наступних 20-50 років, при розробці планів модернізації зрошувальних систем норми водопотреби слід збільшити ще на 10-20\% порівняно з районованими нормами. Одночасно поряд 3 визначенням загальних обсягів потрібних водних ресурсів важливо врахувати особливості внутрішньосезонного розподілу дефіциту водоспоживання сільськогосподарських культур та гідромодулю водоподачі на зрошення при типових схемах сівозмін, що зараз використовуються у виробництві.

Аналіз проявів посушливих явищ у господарствах протягом вегетаційних періодів 2012-2017 pp.

За період 2012-2017 рр. по двох пілотних господарствах у Херсонській області, де встановлено автоматизовані метеостанції, було виконано оцінку частоти i iнтенсивності посух, детальний аналіз погодних умов за цей період та їх впливу на продуктивність сіль- ськогосподарських культур на прикладі сої середньостиглої. Аналіз виконували за трьома укрупненими періодами розвитку.

Співставлення тривалості міжфазних періодів показало, що перший і третій періоди змінювалися по роках у широких межах (у півтора - два рази), що залежить значною мірою від температури повітря та вологозабезпеченості посівів. Другий (критичний) період був більш стабільним і його тривалість коливалась від 23 до 30 днів.

Аналіз даних метеорологічних спостережень свідчить, що близьким до норми за природною водозабезпеченістю поряд 32013 р. був 2012 р., хоча внутрішньо сезонний розподіл опадів відрізнявся: більш вологим критичний період був у 2013 р., а третій період - у 2012 р. 3 6-ти років найбільша кількість опадів спостерігалась у 2014 та 2016 роках (близько $150 \%$ норми), а найменша - у 2015 р., всього $90 \%$ норми. В усі роки досліджень найбільш забезпеченим опадами був перший період вегетації, в той час як критичний період, що має найбільший вплив для формування продуктивності, був дуже посушливим у 2012 та 2014 роках.

На рис. 4 наведено розподіл кількості опадів за трьома періодами вегетації (\%) сої. Найбільш забезпеченим опадами за всі роки спостережень був 1-й період (62\%), посушливим - 3-й. Критичний період відрізнявся найбільшою варіацією опадів - від 5 до $32 \%$. Цей приклад $є$ свідченням необхідності урахування внутрішньо сезонного розподілу параметрів погодних умов при розробці проектів модернізації зрошувальних систем, складанні річних планів водокористування та при оперативному плануванні зрошення.

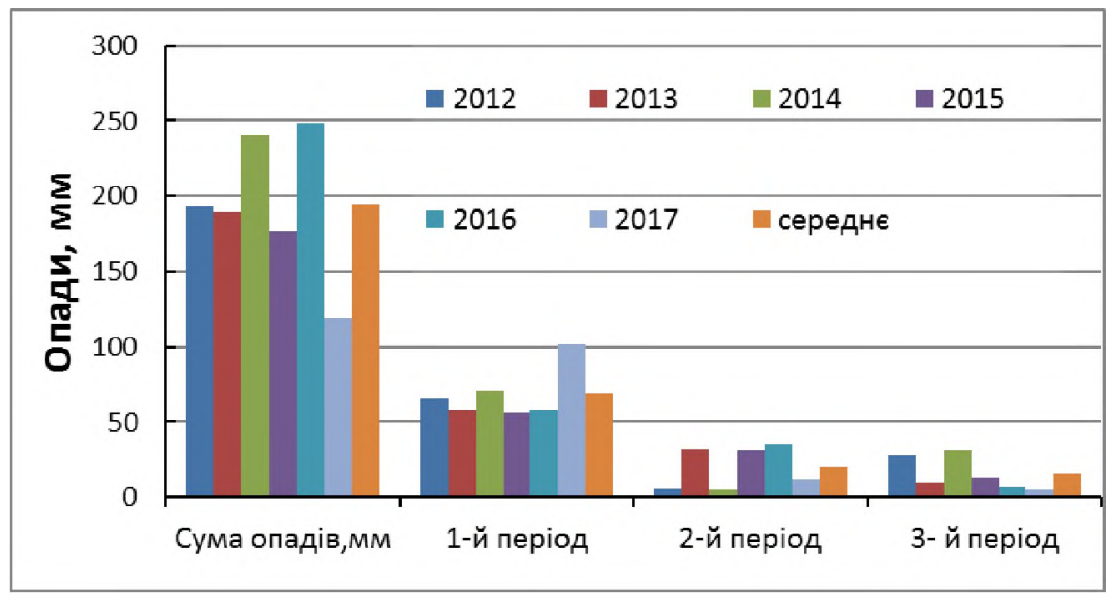

Рис. 4. Сума опадів за вегетаційний сезон (мм) та варіація розподілу суми опадів по укрупнених періодах вегетації сої середньостиглої за роки досліджень в ДП «ДГ «Асканійське» АДСДС І3З НААН» 
Тривалість бездощових періодів була найбільшою (54-75 днів) у 2013 та 2015 роках, а середні її значення - у межах 25-30 днів.

Теплозабезпеченість с.-г. культур визначається сумою активних температур за періодами вегетації. В усі роки досліджень вона перевищувала $2500^{\circ} \mathrm{C}$, що забезпечувало нормальний ріст та розвиток культури. Найбільш забезпеченим теплом був 2014 р., коли сума температур досягала $3200^{\circ} \mathrm{C}$. Аналіз даних відносної вологості повітря показав, що у критичний період розвитку сої вона складала 60-72\%, у перший період розвитку $-60-87 \%$. Нижчими були їі значення у третьому періоді - від 65 до $41 \%$, що свідчить про наявність у цей час посухи.

Найбільша кількість днів 3 максимальною температурю вище $30^{\circ} \mathrm{C}$ спостерігалася в 2012 році. Днів 3 мінімальною відносною вологістю повітря нижче $30 \%$ було найбільше в 2014 році.

Важливою характеристикою, що визначає величину сумарного випаровування, $є$ швид- кість вітру. У середньому вона була невеликою - 1-3 м/с, але в окремі дні перевищувала 5-7 м/с. Суховійні явища, інтенсивність яких залежить від їх тривалості, коливались у межах 13-32 днів і лише у 2014 p. - 40 днів. Основна їх кількість припадає на 3-й період розвитку сої, а перші два періоди їх повторюваність була менше 10 днів.

Інтенсивність атмосферних посух оцінювали за значеннями ГТК [10], що розраховується за відношенням між сумою опадів та сумою температур за певний період, поділеною на 10. Е.К. Зоідзе запропонував використовувати ГТК для оцінки інтенсивності атмосферної посухи за короткі періоди (місяць), а саме при величині ГТК більше 0,75 атмосферна посуха відсутня, 0,61-0,70 - слабка посуха, 0,40-0,60 середня, $0,20-0,39$ - сильна, $\leq 0,19-$ дуже сильна $[11,12]$.

На рис. 5 наведено результати визначення інтенсивності та тривалості посух за результатами розрахунку ГТК.

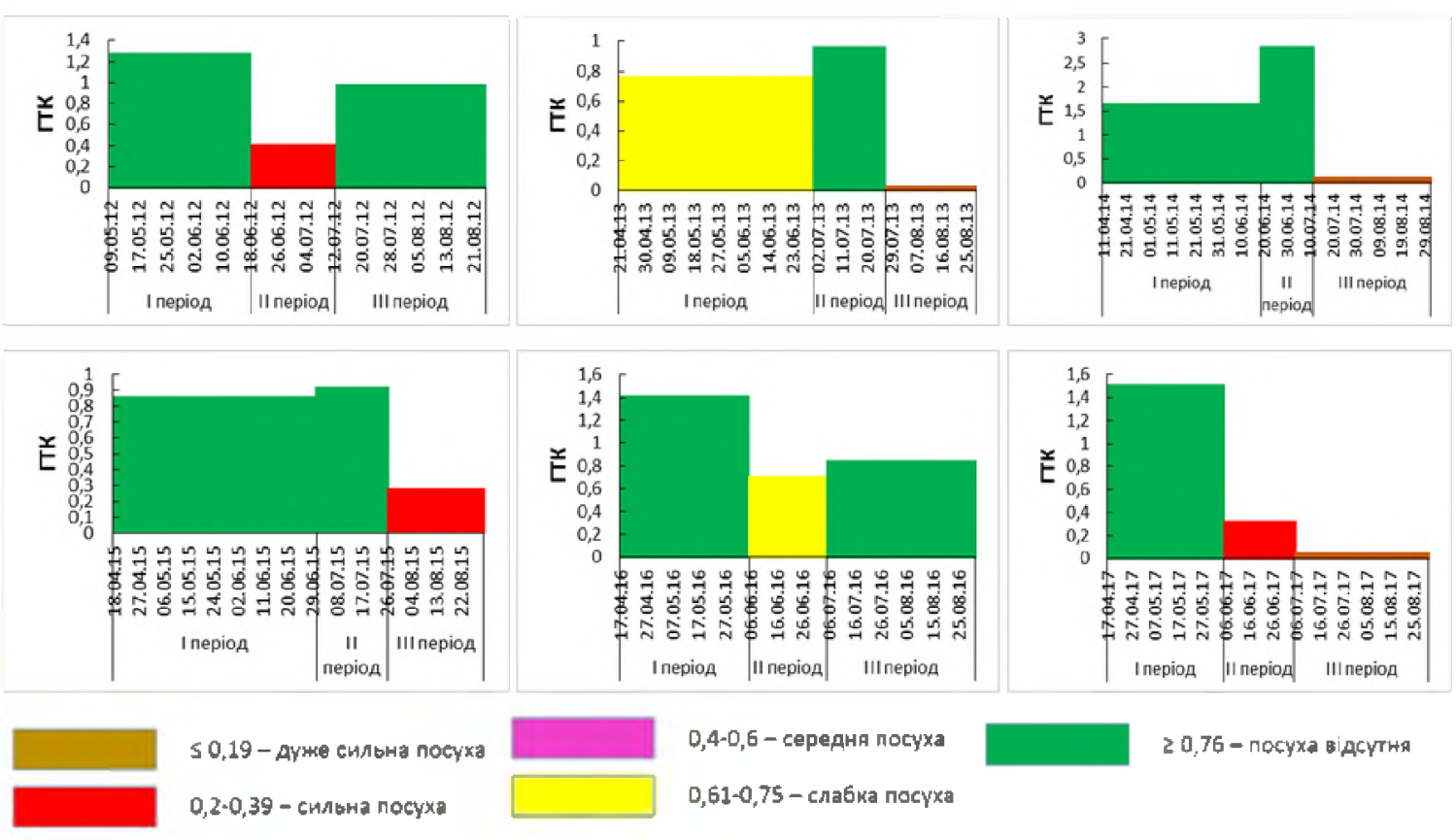

Рис. 5. Значення ГТК за міжфазні періоди у роки досліджень

За показниками ГТК літньо-осіння атмосферна посуха спостерігалась у 2013 р., а літня у 2015, 2017 pp. За шість років досліджень особливо тривалою була посуха 2017 р., коли посушливою була більша частина літа (випало всього 76 мм опадів при нормі 115 мм), а величина ГТК знаходилася у межах від 0,31 до 0,03 .

Виконаними дослідженнями підтверджено той факт, шо за гостро посушливих умов, незважаючи на інтенсивне зрошення, відбувається зниження швидкості приросту біомаси рослин. Звичайно, що приріст біомаси відбувається постійно, проте об'єм утворення сухої речовини знижується.

Так, у 2014 р. на початку сезону й протягом критичного періоду температура повітря піднімалась вище $30^{\circ} \mathrm{C}$, проте періоди були нетривалими (до 5 днів). Починаючи 38 липня 
2014 р. денна температура повітря трималася вище оптимальної $\left(30^{\circ} \mathrm{C}\right)$ протягом 40 днів. Температура в ці дні сягала $39^{\circ} \mathrm{C}$, мінімальна відносна вологість повітря знижувалась до $10 \%$, в окремі дні швидкість вітру досягала
7 м/с. 3 другого спекотного тижня приріст біомаси почав знижуватись, а на 6-му тижні приріст становив лише 214 кг/га. Після зниження температури та випадіння опадів приріст сухої речовини трішки підвищився (рис. 6).

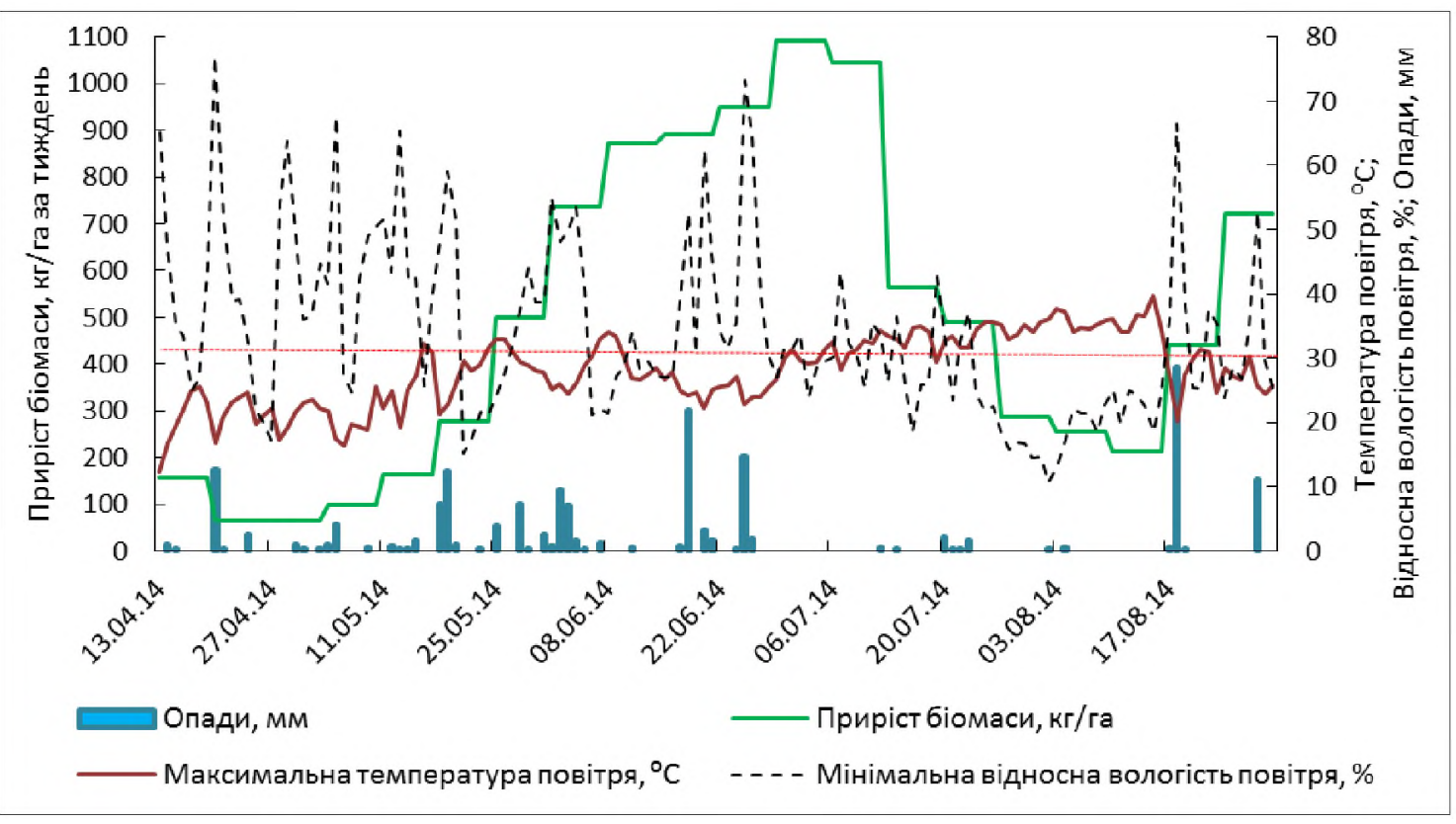

Рис. 6. Динаміка приросту біомаси сої середньостиглої в 2014 р.

залежно від метеорологічних показників (максимальна температура та мінімальна відносна вологість повітря, опади) в ПрАТ «Фрідом Фарм Інтернешнл»

Зменшення приросту біомаси при тривалих та інтенсивних посухах впливає на рівень водоспоживання рослин. Значення сумарного випаровування (евапотранспіраціі), що отримано за допомогою інформаційної системи космічного моніторингу «Fieldlook», свідчить про суттєве зменшення водоспоживання сої у роки, коли спостерігалась сильна та дуже сильна посуха

За результатами досліджень окремих років, шо визначались різними умовами прояву посухи, побудовано залежності (рис. 7) між приростом біомаси та евапотранспірацією протягом тижня.

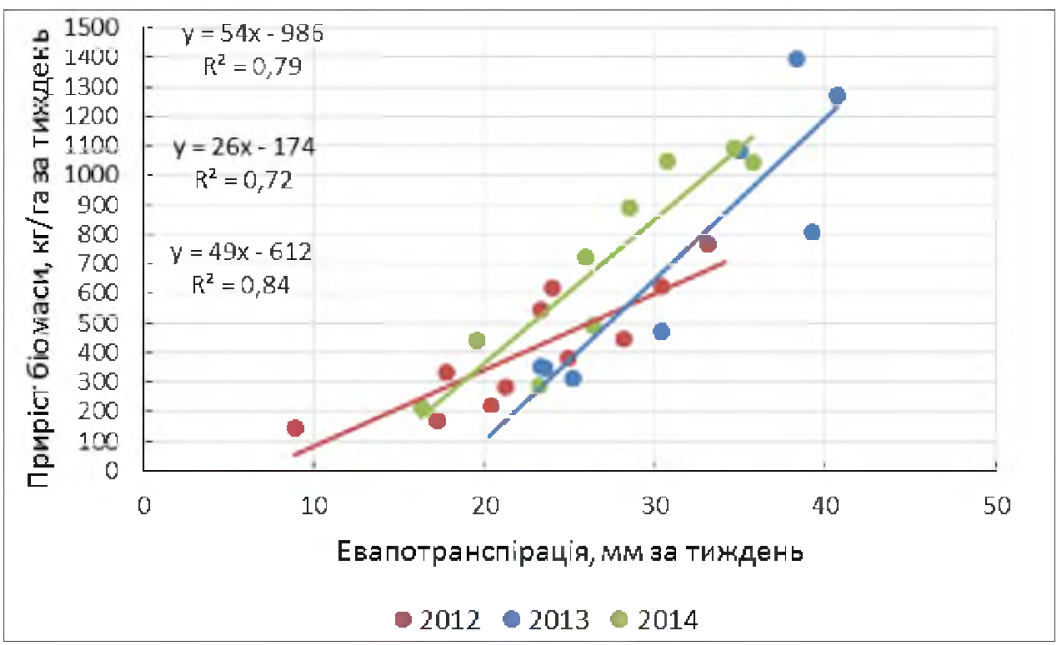

Рис. 7. Залежність між приростом біомаси сої середньостиглої та евапотранспірацією за даними IC «Fieldlook» в 2012-2014 pp. 
Отримані залежності свідчать про відмінності процесів транспірації сої у роки з різною інтенсивністю посухи, що обумовлює необхідність внесення поправочного коефіцієнта до нормативного біокліматичного коефіцієнта при використанні розрахункових методів визначення евапотранспірації.

Дані поправочного коефіцієнта для років досліджень визначалися як відношення між значеннями евапотранспірації, що одержували за даними «Fieldlook» iз врахуванням фактичного приросту біомаси та результа- тами розрахунку евапотранспірації за IC «ГІС Полив», що використовують нормативні біокліматичні коефіцієнти без врахування впливу посухи на динаміку транспірації рослин та приріст біомаси. Обробка результатів досліджень дозволила встановити залежність тривалості днів з температурами більше $30^{\circ} \mathrm{C}$ та величинами поправочних коефіцієнтів, що дає можливість коригувати розрахунки евапотранспірації залежно від інтенсивності прояву посухи у конкретному році (рис. 8).

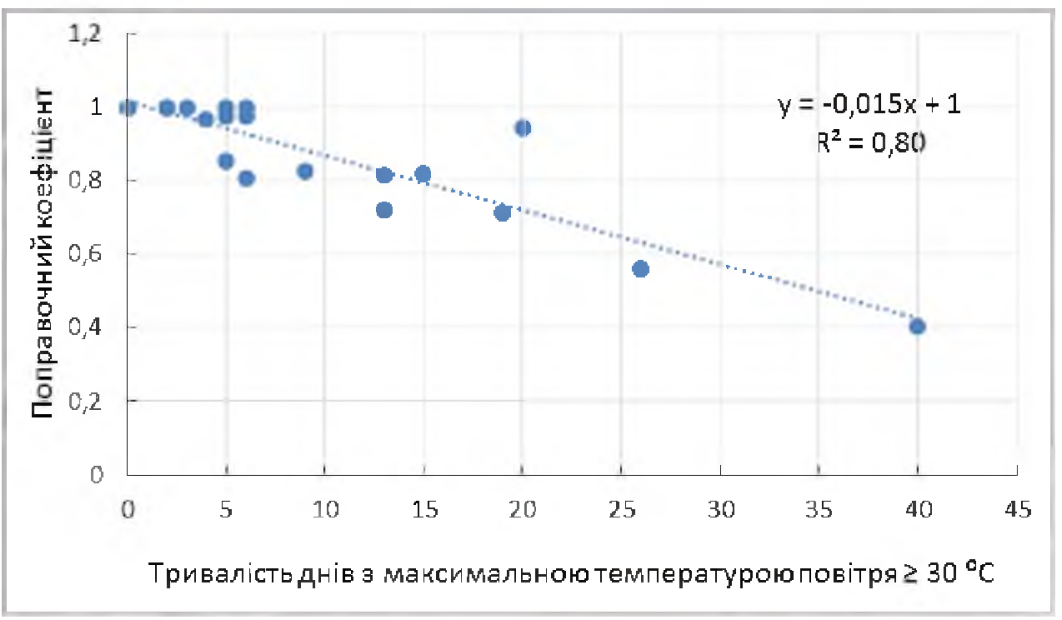

Рис. 8. Залежність між поправочним коефіціснтом та тривалістю періоду з денними температурами більше $30^{\circ} \mathrm{C}$

Коригування біокліматичних коефіціснтів в умовах посухи забезпечує адекватне визначення потріб̈них обсягів води для поливу 3 врахуванням фактичного стану біомаси рослин та редукції евапотранспірації. Але для підтримання оптимальних умов водоспоживання та запобігання негативному впливу посухи важливим $є$ управління мікрокліматом посівів за рахунок зниження температури та підвищення вологості повітря у приземному шарі грунту. Цього можна досягти за рахунок проведення в посушливі періоди зволожувальних поливів невеликим нормами, що можливо лише за умов застосування сучасної дощувальної техніки та поєднання цього заходу $з$ іншими заходами, що можуть забезпечувати аналогічний мікрокліматичний ефект: оптимізація густоти посівів, облаштування лісосмуг, застосування мінімального обробітку грунту, застосування хімічних препаратів та ін. Існуюча практика зрошуваного землеробства великих полів (60-100 га) при проведенні інтенсивних поливів нормами 400-500 м³/га не запобігає негативному впливу посух на темпи приросту біомаси рослин та відповідно втратам урожаю сільськогосподарських культур. Отже, перед науковцями та виробництвом постає важливе завдання розробки комплексу заходів 3 адаптації зрошуваного землеробства до умов екстремальних посух шляхом розвитку існуючих методів планування зрошення на основі інтегрованого моделювання процесів енергомасообміну у середовищі «грунт - рослина - атмосфера», перегляду існуючих технологій поливу та розробки інновацій щодо ведення землеробства в умовах екстремальних посух.

Висновки. У результаті досліджень змін клімату на регіональному та локальному рівні у зоні Південного Степу України встановлено його потепління протягом вегетаційного періоду сільськогосподарських культур та водночас процеси зростання дії екстремальних погодних явищ, таких як посухи, суховії тощо. За вегетаційні сезони у період 1992-2017 років середньодобові температури повітря порівняно 3 багаторічною нормою збільшились в середньому на $0,8^{\circ} \mathrm{C}$, а в окремі роки на $2,5^{\circ} \mathrm{C}$ (2007 p., 2012 р.)); сума опадів на 55 мм. Зростання посушливості клімату за рахунок високих температур 
повітря обумовлюе необхідність постійного коригування норм водопотреби у зрошенні 3 врахуванням ймовірних кліматичних сценаріїв, як при розробці проектів відновлення та модернізації зрошувальних систем, так і при річному плануванні водокористування на зрошувальних системах та визначенні тарифів водоподачі на зрошення у господарства.

На фоні загального потепління клімату протягом останніх 6-ти років постійно спостерігались сильні та дуже сильні посухи у період критичного розвитку та наприкінщі вегетації сільськогосподарських культур, тривалість яких досягала 47 днів. У ці періоди розвитку рослини $\epsilon$ найбільш вразливими до високих денних температур $\left(30-35^{\circ} \mathrm{C}\right.$ і більше) та зниження вологості повітря до $30 \%$, тривалість бездощових періодів в окремі роки досягала 75 днів.

За умов екстремальних посух навіть на фоні оптимального зрошення відбувається редукція водоспоживання сільськогосподарських культур та упові.льнення розвитку біомаси. При вирощуванні сої прояви посух стають суттєвими при значеннях гідротермічного коефіцієнта у критичний період розвитку рослин у діапазоні 0,6-0,2 та 0,2-0,1 в останній період вегетації. За таких умов при плануванні режимів зрошення необхідно коригувати параметри моделей водоспоживання на основі даних водобалансових досліджень та результатів космічних знімків.

Для запобігання та пом'якшення негативного впливу посух на зрошуваних масивах Південого С тепу України необхідним є запровадження інтегрованих заходів 3 управління мікрокліматом посівів шляхом: проведення зволожуючих поливів невеликим нормами; оптимізації густоти посівів; впровадження мінімальних технологій обробітку грунту та інших заходів.

\section{Бібліографія}

1. Предстоящие изменения климата. Совместный советско-американский отчет о климате и его изменениях. / Под ред. Будыко М.И. и др. Ленинград: Гидрометеоиздат, 1991. $272 c$.

2. Кульбіда М. І., Єлістратова Л. О., Барабаи М. Б. Сучасний стан клімату Украйни // Проблеми охорони навколиинього природного середовища та екологічной безпеки. 2013. Bun. 35. C. $118-130$.

3. Районування території Украйни за рівнем забезпеченості гідротермічними ресурсами та обсягами використання сільськогосподарських меліорацій / Тараріко Ю.О. та ін. Київ: ЦП «Компринт», 2015. 62 c.

4. Управління процесом відновлення та сталого використання зроиення // Меліорація $i$ водне господарство / Ромащенко М.I. та ін. Кийв: ВП «Едельвейс», 2014. Bun. 101. C. 137-147.

5. "Комп'ютерна програма «Інформаційна система оперативного планування зроиення IC «ГІС Полив» («IС «ГІС Полив»»)», автори: Жовтоног О.І. та ін. (Свідочтво про реєстрацію авторських прав на твір № 54650 від 07.05.2014)

6. Assessment of climate impact on vegetation dynamics by using remote sensing // Physics and Chemistry of the Earth. Roerink, G.J. et. ISSN 1474-7065. 2003. №28. P. 103-109.

7. Інструменти підтримки прийняття рімень у зроиуваному землеробстві за даними наземного та дистанційного моніторингу // Збірник статей Науково-практичной конференції із міжнародною участю "Вода: проблеми та иляхи вирімення"/ Жовтоног О.I. та ін. Житомир: Вид-во ЕЦ «Укрекобіокон», 2017. С. 108-114.

8. Спутниковый анализ состояния вачих полей [Електронний ресурс]-Режсим доступа: www.fieldlook.ru, для достуnа до інформ.ресурсам потрібна авторизація. - Назва з екрану

9. Дмитренко В.П. Погода, клімат і урожай польових культур. Кийв: Ніка-Центр, 2010, 620 c. ISBN 978-966-521-532-5

10.Селянинов Г.Т. Происхождение и динамика засух. В кн.: Засухи в СССР. Их происхождение, повторяемость и влияние на урожай. Ленинград: Гидрометеоиздат, 1958. С. 5-29.

11.Грингоф И. Г., Пасечнюк А.Д. Агрометеорология и агрометеорологические наблюдения, СПб., 2005. $552 \mathrm{c}$.

12. Зоидзе Е. К. О подходе к исследованию неблагоприятныхх агроклиматических явлений в условиях изменения климата в Российской Федерации // Метеорология и гидрология. 2004. Вып. 1. 96 с.

13. Укрупненные нормы водопотребности для орочения по природно-климатическим зонам СССР: Утв. М-вом мелиорации и вод. хоз-ва СССР 12.12.83. [Срок введ. в действие 01.01.84]. M. : Б. u., 1984. 346 c. 
14.Тимчасові районовані норми водопотреби сільськогосподарських культур для зрочення доиуванням/Жовтоног О.І. та ін. Київ: Аграрна наука, 2015. 24 с.

\section{References}

1. Budyko, M.I., Izrael, Yu. A., Makkaraken, M.S., Hekkta, A.D. (Ed.). (1991). Predstoyashchiye izmeneniya klimata. Sovmestnyi sovetsko-amerikanskiy otchet o klimate i yego izmeneniyakh [The upcoming climate change. Joint Soviet-American report on climate and its changes]. Leningrad: Gidrometeoizdat. [in Russian].

2. Kulbida, M.I., Elistratova, L.O., Barabash, M. B. (2013). Suchasnyy stan klimatu Ukrayiny. Problemy okhorony navkolyshn'oho pryrodnoho seredovyshcha ta ekolohichnoyi bezpeky [The current state of Ukraine's climate. Problems of environmental protection and ecological safety]. Kharkiv: Raider. [in Ukrainian]

3. Tarariko, YU.O., Saydak, R.V., Soroka, YU.V., Vitvits'kyy, S.V. (2015). Rayonuvannya terytoriyi Ukrayiny za rivnem zabezpechenosti hidrotermichnymy resursamy ta obsyahamy vykorystannya sil's'kohospodars'kykh melioratsiy [The zoning of the territory of Ukraine by the level of availability of hydrothermal resources and volumes of use of agricultural land reclamation]. Kyiv: Komprint. [in Ukrainian]

4. Romashchenko, M.I., Zhovtonog, O.I., Kruchenyuk, V.D., Saydak, R.V., Knysh V.V. (2014). Upravlinnya protsesom vidnovlennya ta staloho vykorystannya zroshennya. Melioratsiya $i$ vodne hospodarstvo [Managing the restoration and sustainable use of irrigation]. Kyiv. [in Ukrainian]

5. Zhovtonoh, O.I.,Filipenko, L.A., Demenkova, T.F., Babych, V.A., Polishchuk, V.V. (2014). Komp'yuterna prohrama. Informatsiyna systema operatyvnoho planuvannya zroshennya IS GIS Polyv [Computer program Informational system of irrigation planning](Svidotstvo pro reyestratsiyu avtors'kykh prav na tvir № 54650 vid 07.05.2014. [in Ukrainian]

6. Roerink, G. J., Menenti, M., Soepboer, W., \& Su, Z. (2003). Assessment of climate impact on vegetation dynamics by using remote sensing. Physics and chemistry of the earth.

7. Zhovtonog, O.I., Polishchuk, V.V., Didenko, N.O., Bulba, YA.O., Salyuk, A.F. (2017). Instrumenty pidtrymky pryynyattya rishen' u zroshuvanomu zemlerobstvi za danymy nazemnoho ta dystantsiynoho monitorynhu [Decision Support Tools in irrigated agriculture, according field and remote monitoring]. Voda: problemy ta shlyakhy vyrishennya: Mizhnarodna nauk.-praktych. konf. Zhytomyr, 108-114. [in Ukrainian]

8. Sputnikovyy analiz sostoyaniya vashikh poley [Satellite analysis of the fields'conditions]. (n.d.) Retrieved from https:/ www fieldlook. ru.

9. Dmytrenko, V.P. (2010). Pohoda, klimat i urozhay pol'ovykh kul'tur [Weather, climate and field crops]. Kyiv: Nika-Tsentr. [in Ukrainian]

10.Selyaninov, G.T. (1958). Proiskhozhdeniye i dinamika zasukh. Zasukhi v SSSR. Ikh proiskhozhdeniye, povtoryayemost' $i$ vliyaniye na urozhay [The origin and dynamics of droughts. In the book: Drought in the USSR. Their origin, repeatability and impact on yield]. Leningrad: Gidrometeoizdat, 5-29. [in Russian]

11. Gringof, I. G., Pasechnyuk, A.D. (2005). Agrometeorologiya i agrometeorologicheskiye nablyudeniya [Agrometeorology and agrometeorological observations]. [in Ukrainian]

12.Zoidze, Ye. K. (2004). O podkhode $k$ issledovaniyu neblagopriyatnykh agroklimaticheskikh yavleniy $v$ usloviyakh izmeneniya klimata $v$ Rossiyskoy Federatsii. Meteorologiya i gidrologiya [On the approach to the study of adverse agro-climatic phenomena in a changing climate in the Russian Federation. Meteorology and hydrology]. [in Ukrainian]

13. Ukrupnennyye normy vodopotrebnosti dlya orosheniya po prirodno-klimaticheskim zonam SSSR: Utv. M-vom melioratsii i vod. khoz-va SSSR 12.12.83. [Integrated water requirements for irrigation in the natural-climatic zones of the USSR: Approved. Ministry of Land Reclamation and Water. Households of the USSR 12.12.83]. [in Ukrainian]

14.Zhovtonog, O.I., Filipenko, L.A., Polishchuk, V.V., Demenkova, T.F., et al (2015). Tymchasovi rayonovani normy vodopotreby sil's'kohospodars'kykh kul'tur dlya zroshennya doshchuvannyam [Temporary water requirements for crops for irrigation with sprinkling]. Kyiv: Ahrarna nauka. [in Ukrainian] 
О.И. Жовтоног, Л.А. Филиппенко, Т.Ф. Деменкова, В.В. Полищук, Я.А. Бутенко Учет изменений климата и интенсивности засух при планировании орошения в зоне Юной Степи Украины

Выполнена оченка изменений теплового режима и природной влагообеспеченности на юге Украины, определена смена среднедекадной температуры воздуха, суммы осадков и увеличение частоты и интенсивности засуиливых явлений. На основе анализа данньх наземных наблюдений и обработки данных дистанционного зондирования Земли предложены методы адаптации режимов оромения в период засуиливьх явлений.

O. Zhovtonog, L. Filipenko, T. Demenkova, V. Polishchuk, Ya. Butenko Irrigation Planning Taking into Account Climate Change and droughts intensity in the Steppes Zone of South Ukraine

An estimation of changes in the thermal regime and natural moisture content in the south of Ukraine has been made. The average air temperature and the amount of precipitation per decade as well as the increase in frequency and intensity of droughts have been determined. Droughts adaptation methods for irrigation planning are proposed based on field observations and Remote Sensing. 